\title{
REVIEW
}

\section{Cervical Lymph Node Metastasis in Adenoid Cystic Carcinoma of the Larynx: A Collective International Review}

Andrés Coca-Pelaz $\cdot$ Leon Barnes - Alessandra Rinaldo - Antonio Cardesa · Jatin P. Shah · Juan P. Rodrigo ·

Carlos Suárez · Jean Anderson Eloy · Justin A. Bishop · Kenneth O. Devaney · Lester D. R. Thompson ·

Bruce M. Wenig · Primož Strojan · Marc Hamoir · Patrick J. Bradley · Douglas R. Gnepp · Carl E. Silver ·

Pieter J. Slootweg • Asterios Triantafyllou • Vincent Vander Poorten • Michelle D. Williams · Alena Skálová •

Henrik Hellquist $\cdot$ Afshin Teymoortash · Jesus E. Medina $\cdot$ K. Thomas Robbins $\cdot$ Karen T. Pitman ·

Luiz P. Kowalski $\cdot$ Remco de Bree $\cdot$ William M. Mendenhall $\cdot$ Robert P. Takes $\cdot$ Alfio Ferlito

Received: January 11, 2016 / Published online: March 19, 2016

(C) The Author(s) 2016. This article is published with open access at Springerlink.com

\section{ABSTRACT}

Adenoid cystic carcinoma (AdCC) of the head and neck is a well-recognized pathologic entity that rarely occurs in the larynx. Although the 5-year locoregional control rates are high,

This article was written by members and invitees of the International Head and Neck Scientific Group (http:// www.IHNSG.com).

Enhanced content To view enhanced content for this article go to http://www.medengine.com/Redeem/ A944F060610F929C.

A. Coca-Pelaz $\cdot$ J. P. Rodrigo

Department of Otolaryngology, Hospital

Universitario Central de Asturias, Oviedo, Spain

L. Barnes

Department of Pathology, University of Pittsburgh

School of Medicine, Pittsburgh, PA, USA

A. Rinaldo

University of Udine School of Medicine, Udine, Italy

A. Cardesa

Department of Anatomic Pathology, Hospital

Clinic, University of Barcelona, Barcelona, Spain

J. P. Shah

Head and Neck Surgery, Memorial Sloan Kettering

Cancer Center, New York, NY, USA distant metastasis has a tendency to appear more than 5 years post treatment. Because AdCC of the larynx is uncommon, it is difficult to standardize a treatment protocol. One of the controversial points is the decision whether or not to perform an elective neck dissection on these patients. Because there is contradictory information about this issue, we have critically reviewed the literature from 1912 to 2015 on all reported cases of AdCC of the larynx in order to clarify this issue. During the most recent period of our review (1991-2015) with a more exact diagnosis of the tumor

\section{J. P. Rodrigo · C. Suárez}

Instituto Universitario de Oncología del Principado de Asturias, University of Oviedo, Oviedo, Spain

\section{Suárez}

Fundación de Investigación e Innovación

Biosanitaria del Principado de Asturias, Oviedo, Spain

\section{J. A. Eloy}

Department of Otolaryngology-Head and Neck Surgery, Neurological Institute of New Jersey, Rutgers New Jersey Medical School, Newark, NJ, USA

\section{J. A. Bishop}

Departments of Pathology and

Otolaryngology-Head and Neck Surgery, The Johns

Hopkins Medical Institutions, Baltimore, MD, USA 
histology, 142 cases were observed of AdCC of the larynx, of which 91 patients had data pertaining to lymph node status. Eleven of the 91 patients $(12.1 \%)$ had nodal metastasis and, based on this low proportion of patients, routine elective neck dissection is therefore not recommended.

Keywords: Adenoid cystic carcinoma; Clinical protocols; Elective neck dissection; Larynx; Lymph node metastasis; Neck; Oncology; Treatment

\section{INTRODUCTION}

Adenoid cystic carcinoma (AdCC) is an uncommon tumor, accounting for about $1 \%$ of all head and neck malignancies [1]. It is typically a slowly growing but relentlessly progressive neoplasm characterized by

K. O. Devaney

Department of Pathology, Allegiance Health,

Jackson, MI, USA

L. D. R. Thompson

Southern California Permanente Medical Group, Woodland Hills, CA, USA

B. M. Wenig

Department of Pathology, Beth Israel Medical

Center, New York, NY, USA

P. Strojan

Department of Radiation Oncology, Institute of

Oncology, Ljubljana, Slovenia

M. Hamoir

Department of Head and Neck Surgery, Head and

Neck Oncology Program, St Luc University Hospital

and King Albert II Cancer Institute, Brussels,

Belgium

P. J. Bradley

Department of Otolaryngology-Head and Neck

Surgery, Nottingham University Hospitals, Queens

Medical Centre Campus, Nottingham, UK

P. J. Bradley · V. Vander Poorten

European Salivary Gland Society, Geneva,

Switzerland perineural invasion, frequent local recurrences and late distant hematogenous dissemination to the lung, liver, bone and brain. In contrast lymph node metastasis, especially true embolic lymph node metastasis, is infrequent. Although the long term prognosis is poor, some patients may survive 10-15 years or more before succumbing to their disease.

In a recent international collaborative study involving nine cancer centers worldwide Amit et al. identified 270 patients with AdCC of the head and neck who underwent neck dissection and observed the overall incidence of neck metastasis to be $29 \%$ [2]. In the same year they also observed a $17 \%$ incidence of occult nodal metastasis among those patients who underwent elective neck dissections [3]. Because of its rarity, it is uncertain whether their data regarding the frequency of lymph node metastasis might also apply to AdCC of the larynx. To address this issue we critically

D. R. Gnepp

University Pathologists, Providence, RI, USA

D. R. Gnepp

University Pathologists, Fall River, MA, USA

C. E. Silver

Departments of Surgery and Otolaryngology - Head and Neck Surgery, Albert Einstein College of

Medicine, Montefiore Medical Center, Bronx, NY, USA

P. J. Slootweg

Department of Pathology, Radboud University Medical Center, Nijmegen, The Netherlands

\section{A. Triantafyllou}

Oral and Maxillofacial Pathology, School of Dentistry, University of Liverpool and Cellular Pathology, Liverpool Clinical Laboratories, Liverpool, UK

V. Vander Poorten Otorhinolaryngology-Head and Neck Surgery and Department of Oncology, Section Head and Neck Oncology, University Hospitals Leuven, KU Leuven, Leuven, Belgium 
reviewed the world literature on AdCC of the larynx in an attempt to suggest guidelines for the management of the neck in patients with AdCC at this anatomic site. This article is based on previously conducted studies and does not involve any new studies of human or animal subjects performed by any of the authors.

\section{REVIEW OF THE LITERATURE AND ANALYSIS}

Minor salivary-type glands are present in most of the laryngeal mucosa: abundantly in the subglottis, false cords/anterior commissure and usually absent from the true cords [4]. Yet despite their presence, glandular neoplasms are distinctly unusual. AdCC is one of the most frequent. Because of their rarity, no single institution has accumulated a large series of cases, and therefore, only single case reports or small series are available for review,

M. D. Williams

Department of Pathology, The University of Texas

MD Anderson Cancer Center, Houston, TX, USA

A. Skálová

Department of Pathology, Faculty of Medicine in Plzen, Charles University in Prague, Plzen, Czech Republic

H. Hellquist

Department of Biomedical Sciences and Medicine, University of Algarve, Faro, Portugal

\section{A. Teymoortash}

Department of Otolaryngology-Head and Neck

Surgery, Philipp University, Marburg, Germany

J. E. Medina

Department of Otorhinolaryngology, The

University of Oklahoma Health Sciences Center,

Oklahoma City, OK, USA

K. T. Robbins

Division of Otolaryngology-Head and Neck Surgery, Southern Illinois University School of Medicine, Springfield, IL, USA

K. T. Pitman

Department of Surgery, Banner MD Anderson

Cancer Center, Gilbert, AZ, USA which often results in widely conflicting data. Eschwege et al. [5] reported five cases of AdCC of the larynx and all were free of cervical lymph node metastasis as opposed to Spiro and Huvos [6] who also reported five cases and observed that four had associated positive lymph nodes (80\%). Accordingly, to appreciate the potential biological behavior of AdCC of the larynx one often must rely on a composite review of published cases. However, this approach is also hampered by lack of quality data. Some cases are poorly documented with no histologic illustrations, and pertinent clinical and/or pathologic details are often not reported, including long term follow-up (more than 10 years). In addition, recent new histopathological entities have been described that may have been or continue to be confused with AdCC, such as basaloid squamous cell carcinoma, polymorphous low grade carcinoma, epithelial-myoepithelial carcinoma,

\section{P. Kowalski}

Department of Head and Neck Surgery and Otorhinolaryngology, A.C. Camargo Cancer Center, São Paulo, Brazil

R. de Bree

Department of Head and Neck Surgical Oncology, UMC Utrecht Cancer Center, University Medical Center Utrecht, Utrecht, The Netherlands

W. M. Mendenhall

Department of Radiation Oncology, University of Florida, Gainesville, FL, USA

R. P. Takes

Department of Otolaryngology-Head and Neck Surgery, Radboud University Medical Center, Nijmegen, The Netherlands

\section{A. Ferlito $(\square)$}

Coordinator of the International Head and Neck Scientific Group, Padua, Italy

e-mail: a.ferlito@uniud.it 
basal cell adenocarcinoma, and cribriform adenocarcinoma.

With these limitations in mind, we undertook a literature search of PubMed (including Medline) using the search strategy "adenoid cystic carcinoma larynx" and "adenoid cystic carcinoma head neck" which resulted in 1292 articles, which were hand-searched for pertinent articles. Their reference lists were also searched for additional cases. We excluded cases without a definitive diagnosis of AdCC, cases where the location of the tumor was not definitely the larynx and cases which were included in previously published reviews (as stated in the table, see remarks). As stated above only a few cases reported include a complete staging procedure, the extent of neck dissections, histology images illustrating the definitive diagnosis, why the authors performed a neck dissection, follow-up of the patient, recurrence of the lesion and location of the recurrence. Our comprehensive review of AdCC of the larynx reported in the literature from 1912 to 2015 includes 252 cases as shown in Table 1 [3, 5-110] (excluded cases have been summarized in Table 2). Based on these data, our review indicates that AdCC of the larynx occurs in individuals averaging 52.3 years of age (range 12-84 years) and is more common in males (60.7\%). The most frequent site of origin is the subglottis $(58.2 \%)$ followed by the supraglottis (32.1\%) and glottis $(9.7 \%)$. Of the 252 cases, the status of the regional lymph nodes was specifically mentioned in 156, and of these 24 (15.4\%) were associated with cervical lymph node metastasis. Due to the lack of sufficiently long term follow-up, the number of 47 cases reported to have had distant metastasis is probably underestimated.

Of the 24 cases with lymph node metastasis, information about the specific location of the tumor within the larynx was available in 16, and of these 9 arose in the supraglottis, 6 in the subglottis and 1 in the glottis.

Over the last century there have been advances in our understanding and classification of salivary tumors and new entities have been described some of which show histologic similarities to AdCC. Accordingly, one might question the authenticity of some of the cases labeled as AdCC of the larynx in the older literature. Considering the fact that basaloid squamous cell carcinoma was first described in 1986 [111], polymorphous low grade adenocarcinoma in 1983 [112], epithelial-myoepithelial carcinoma in 1972 [113], basal cell adenocarcinoma in 1988 [114] and cribriform adenocarcinoma in 1999 [115], all potential histologic mimickers of AdCC, we divided our review into two time periods, (a) 1912-1990 (we have further subdivided this into two time periods due to the description of epithelial-myoepithelial carcinoma in 1972) and (b) 1991-2015 (Table 3), in order to analyze whether the incidence of lymph node metastasis in AdCC of the larynx was higher before the description of these "new" tumors which may have been mistaken histologically for AdCC. Between 1912 and 1990, we identified 110 cases of AdCC of the larynx and, of these, 65 had data regarding lymph node status. Thirteen of these 65 patients (20\%) had lymph node metastasis. For the period 1991-2015, 142 cases were observed and of these reports 91 patients had data pertaining to lymph node status. Eleven of the 91 patients (12.1\%) had nodal metastasis. Possibly, this decline in the incidence of lymph node metastasis between the two time periods might in part be related as noted above to incorrect histological diagnosis prior to 1991, though the difference does not appear statistically significant $\left(\chi^{2}=1.75, \quad d f=1\right.$, $p>0.05)$. 


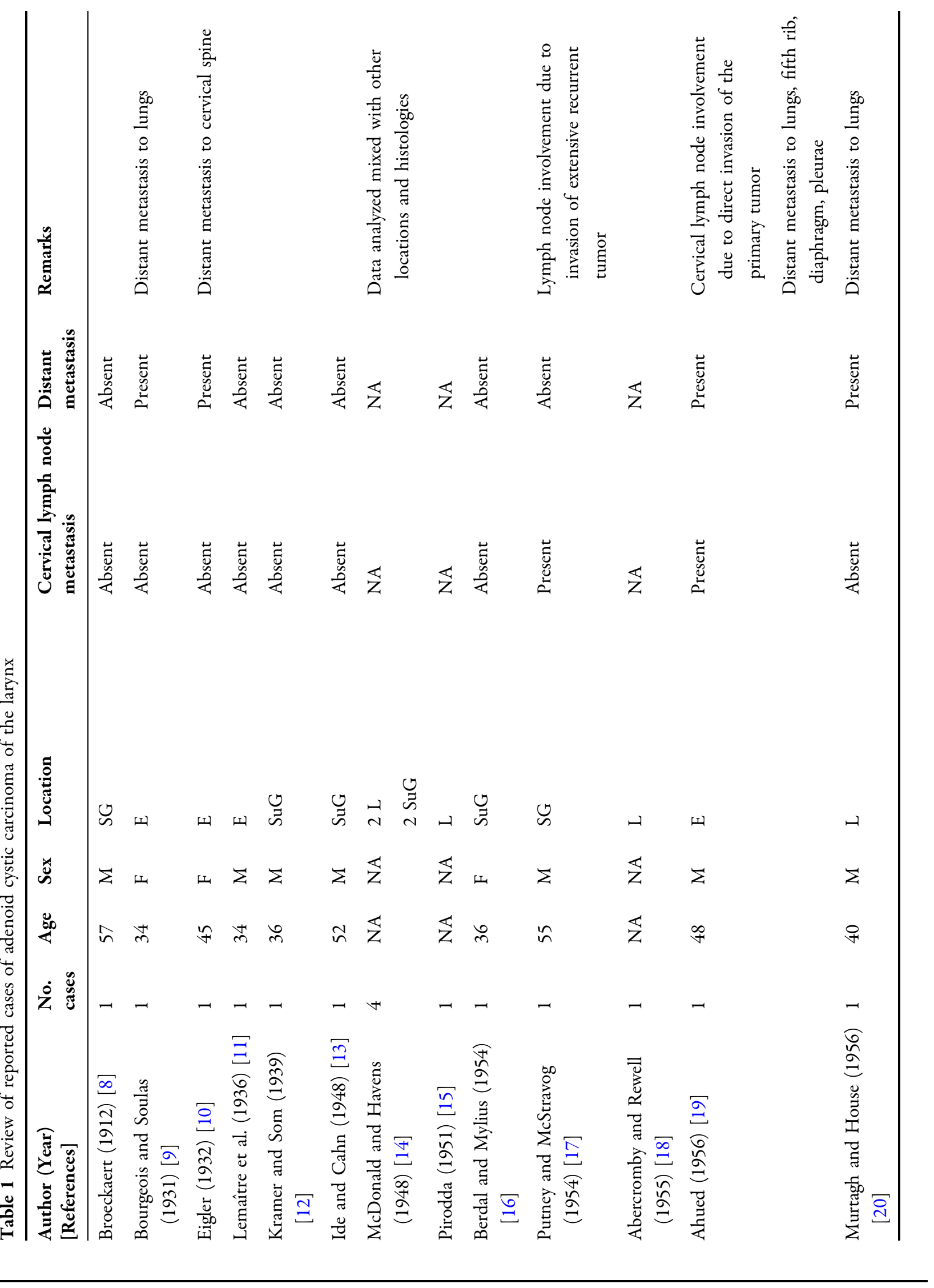




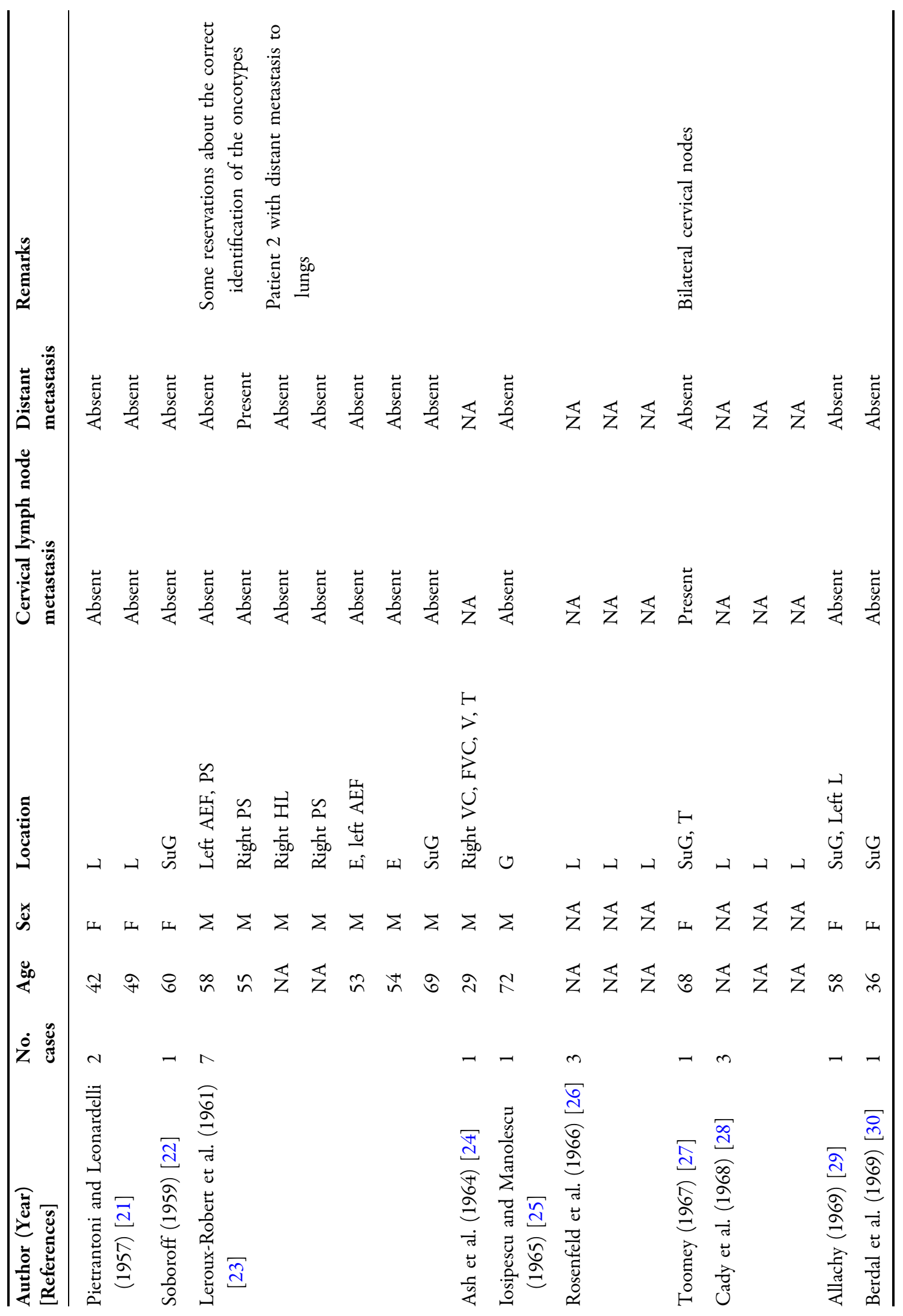




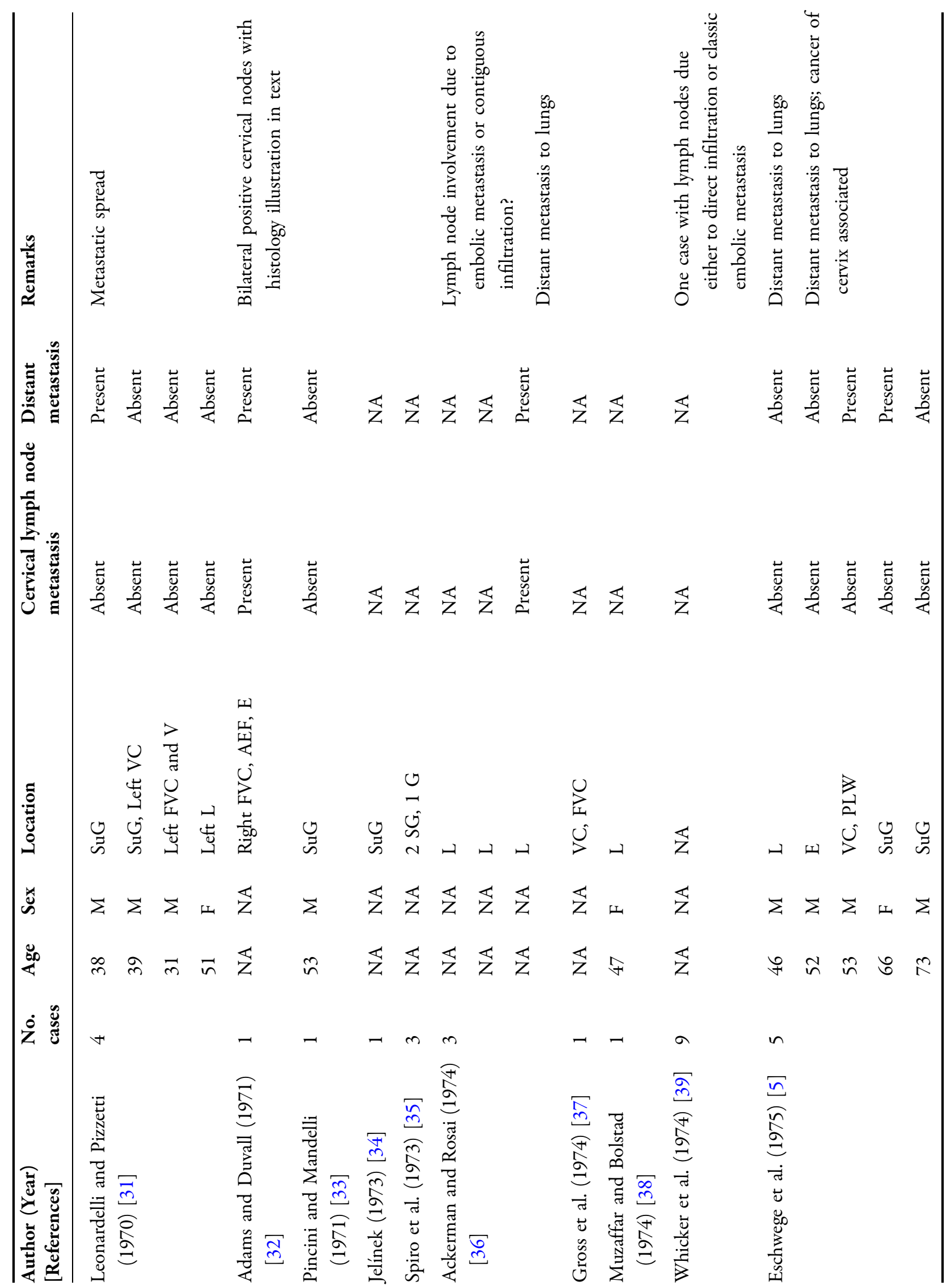




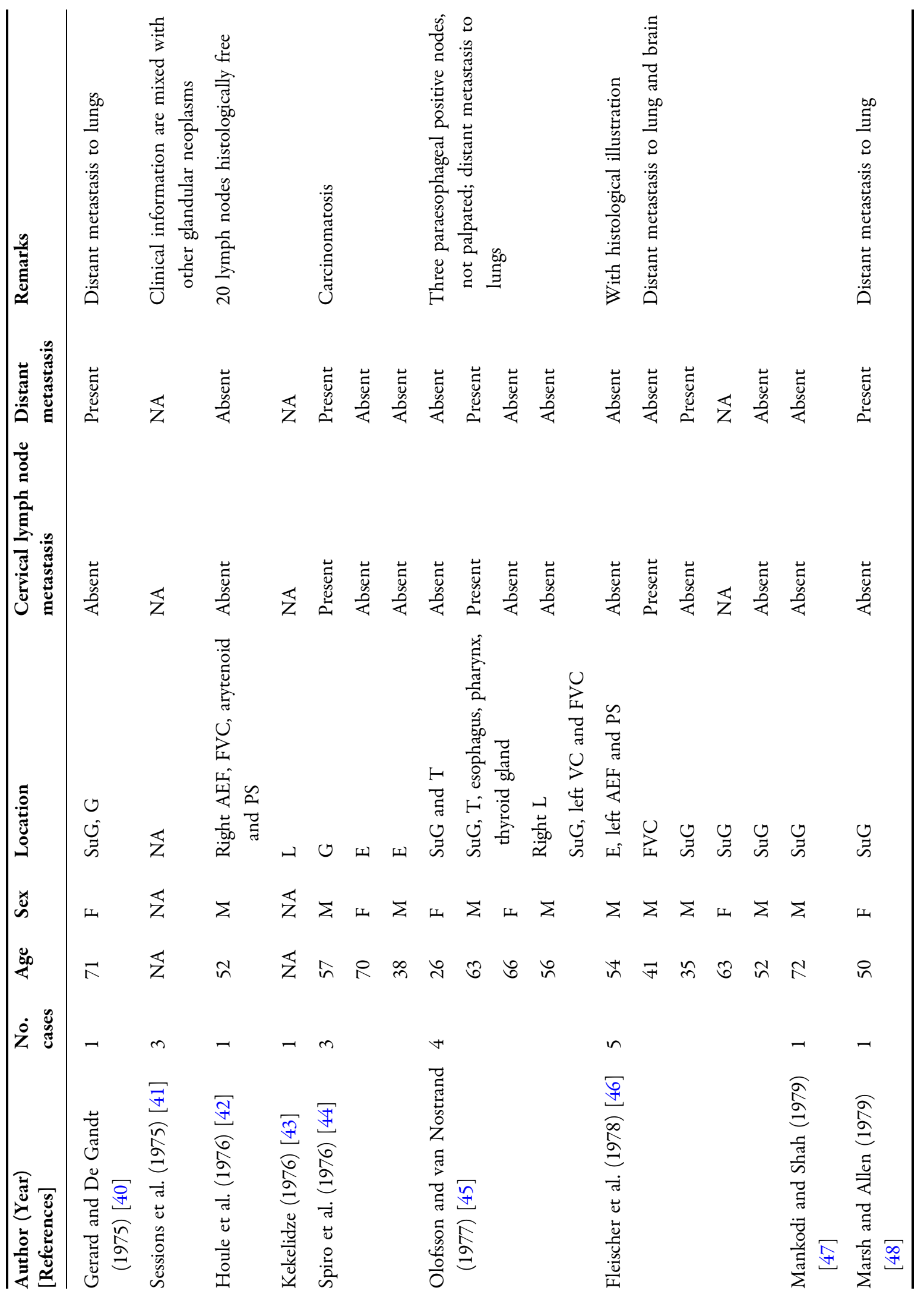




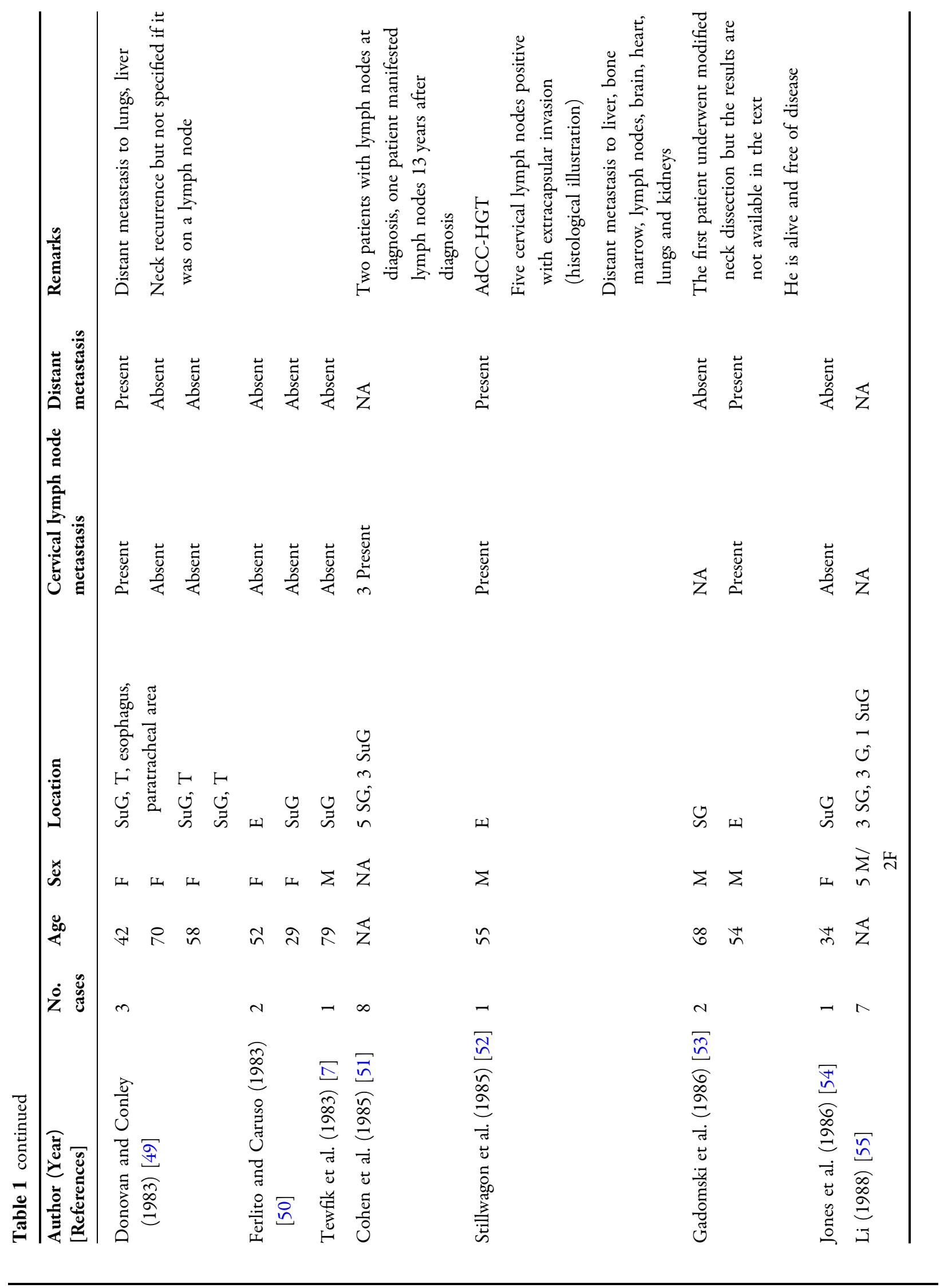




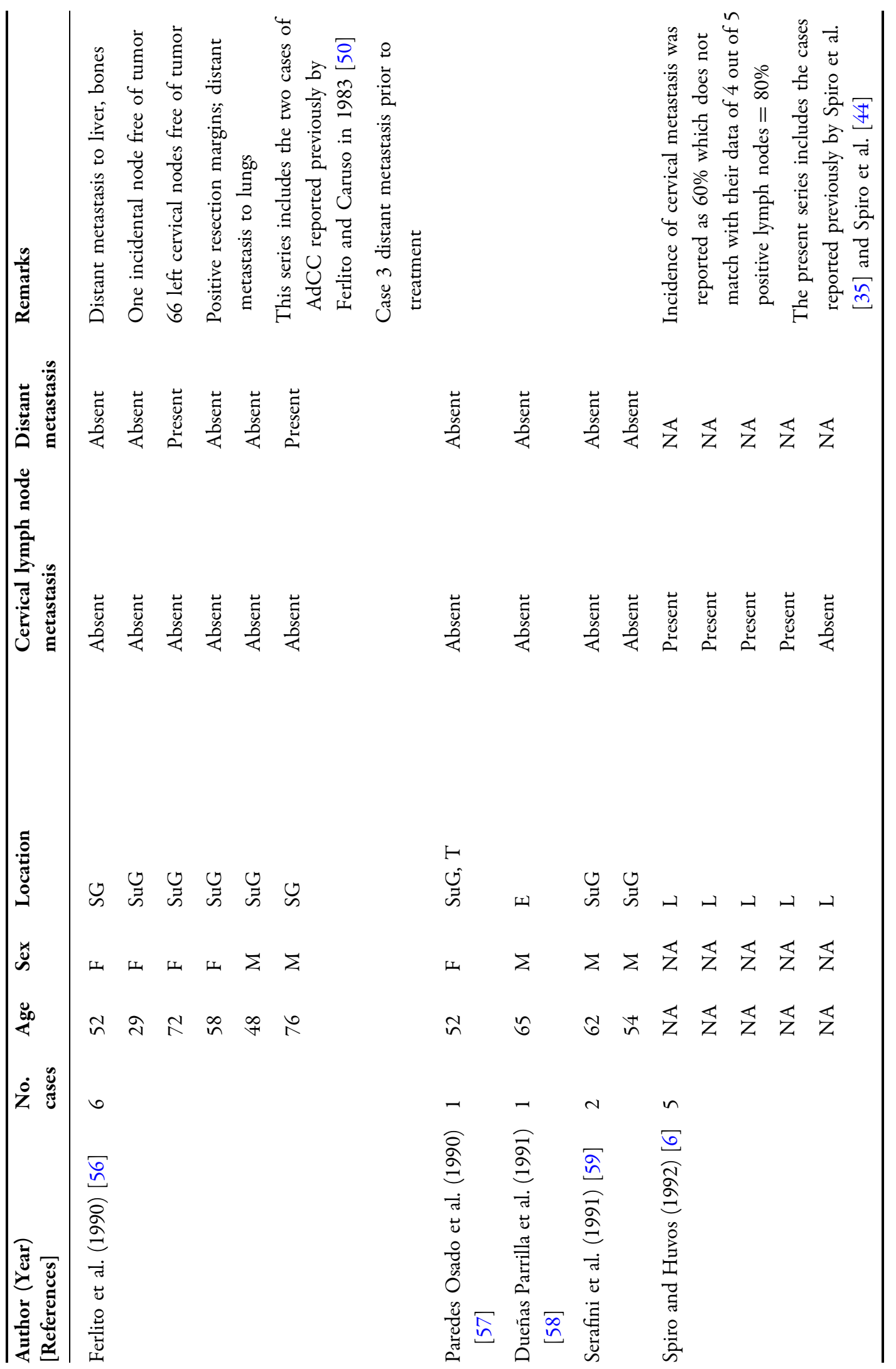




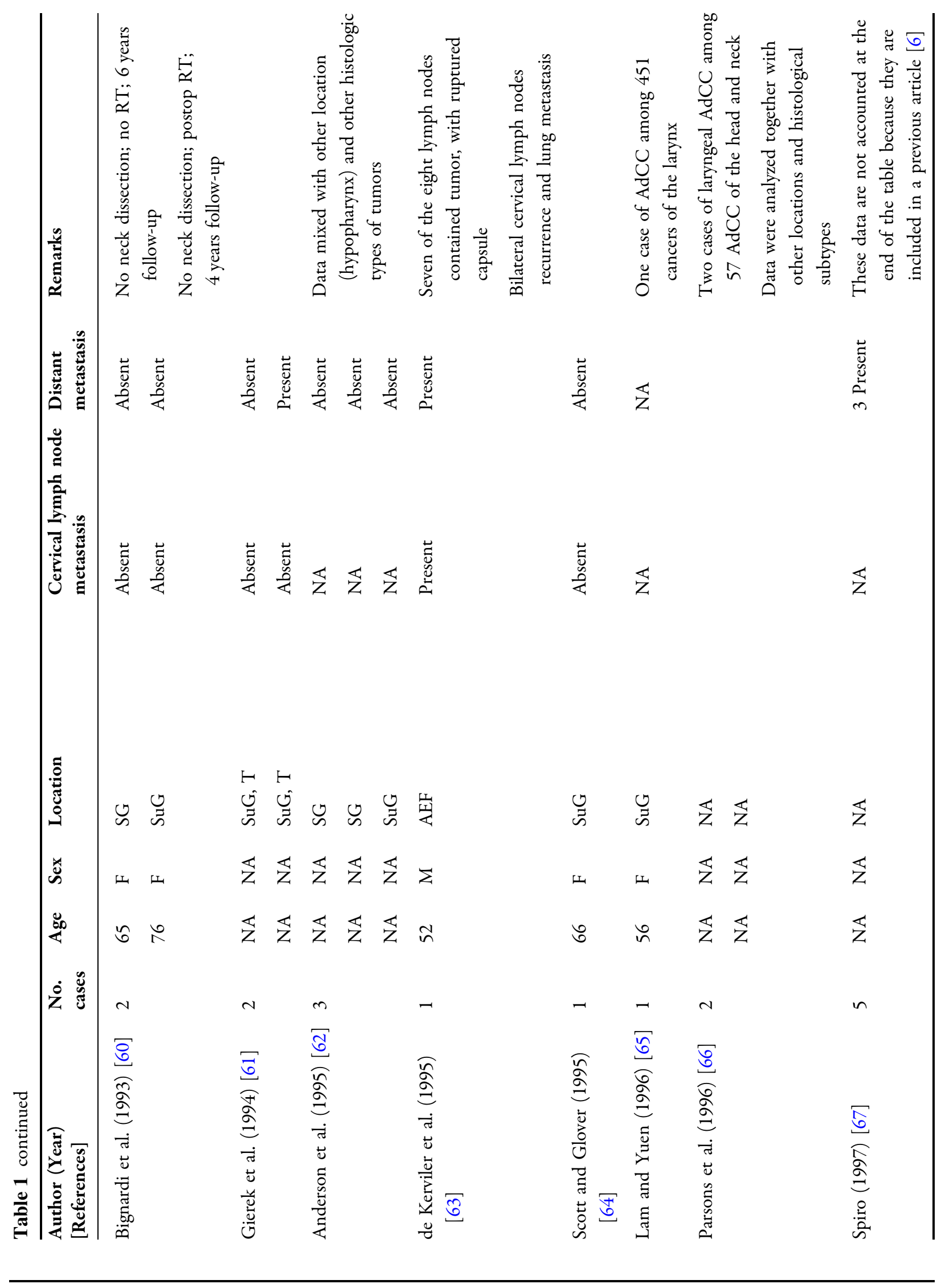




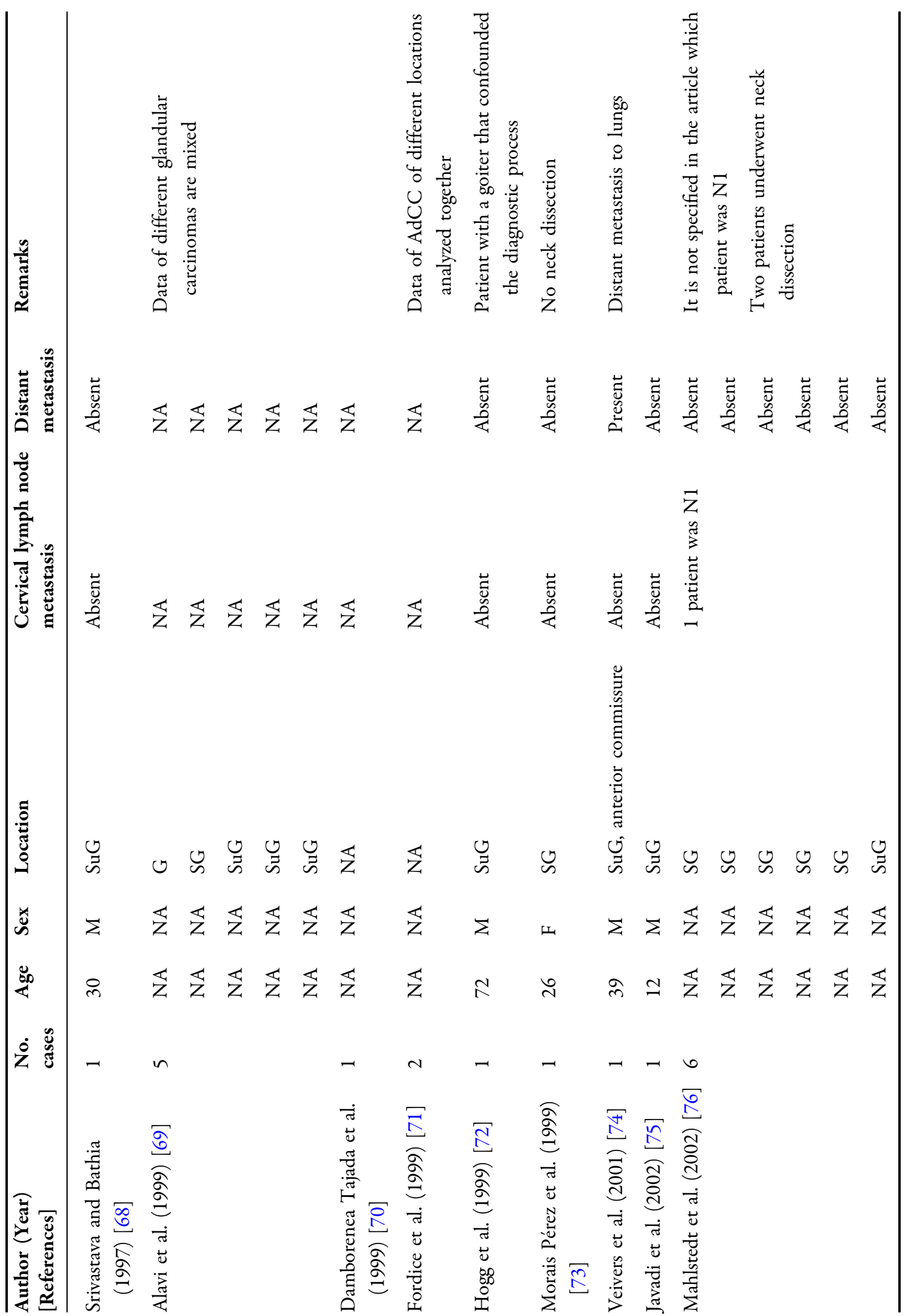




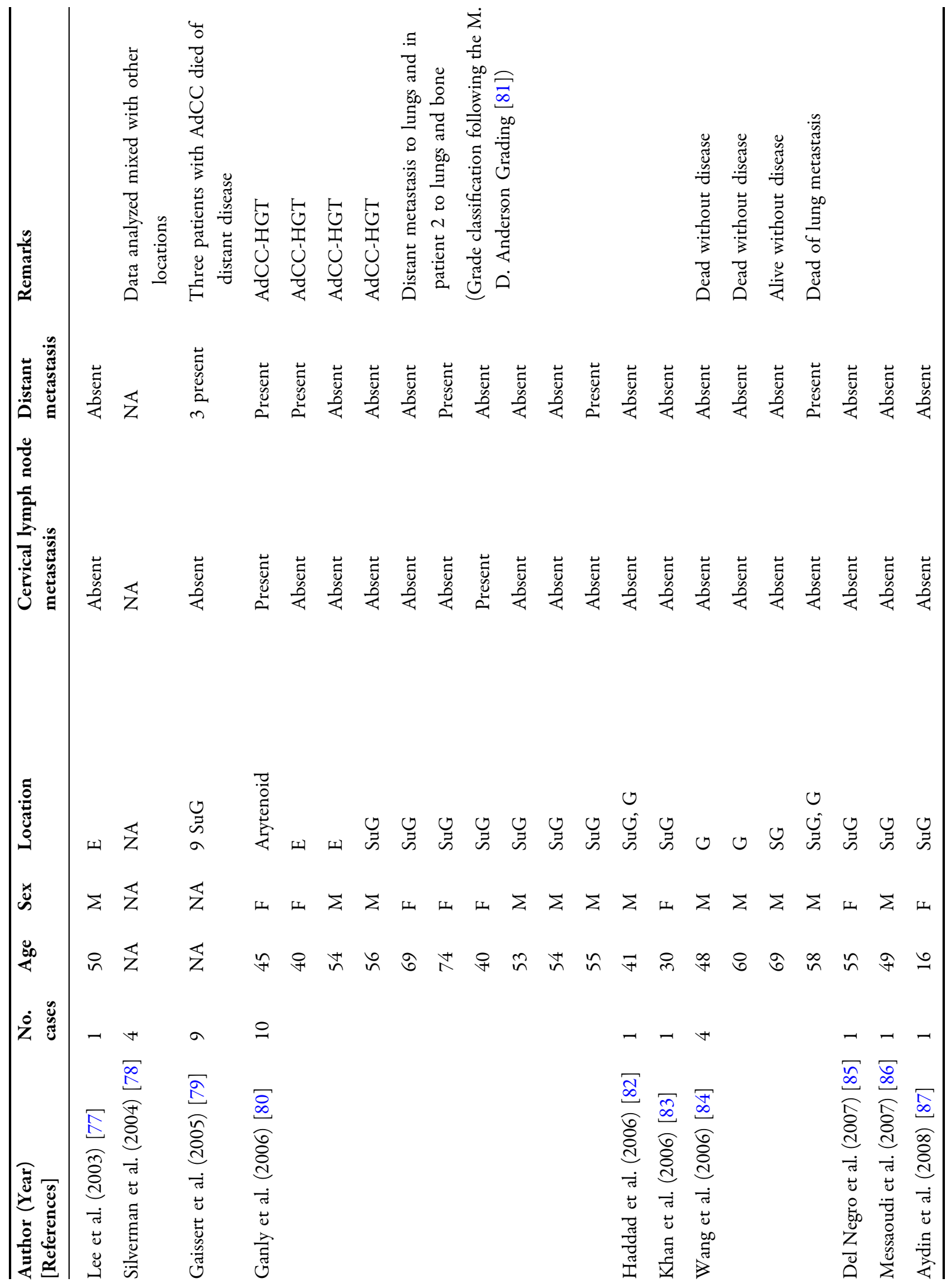




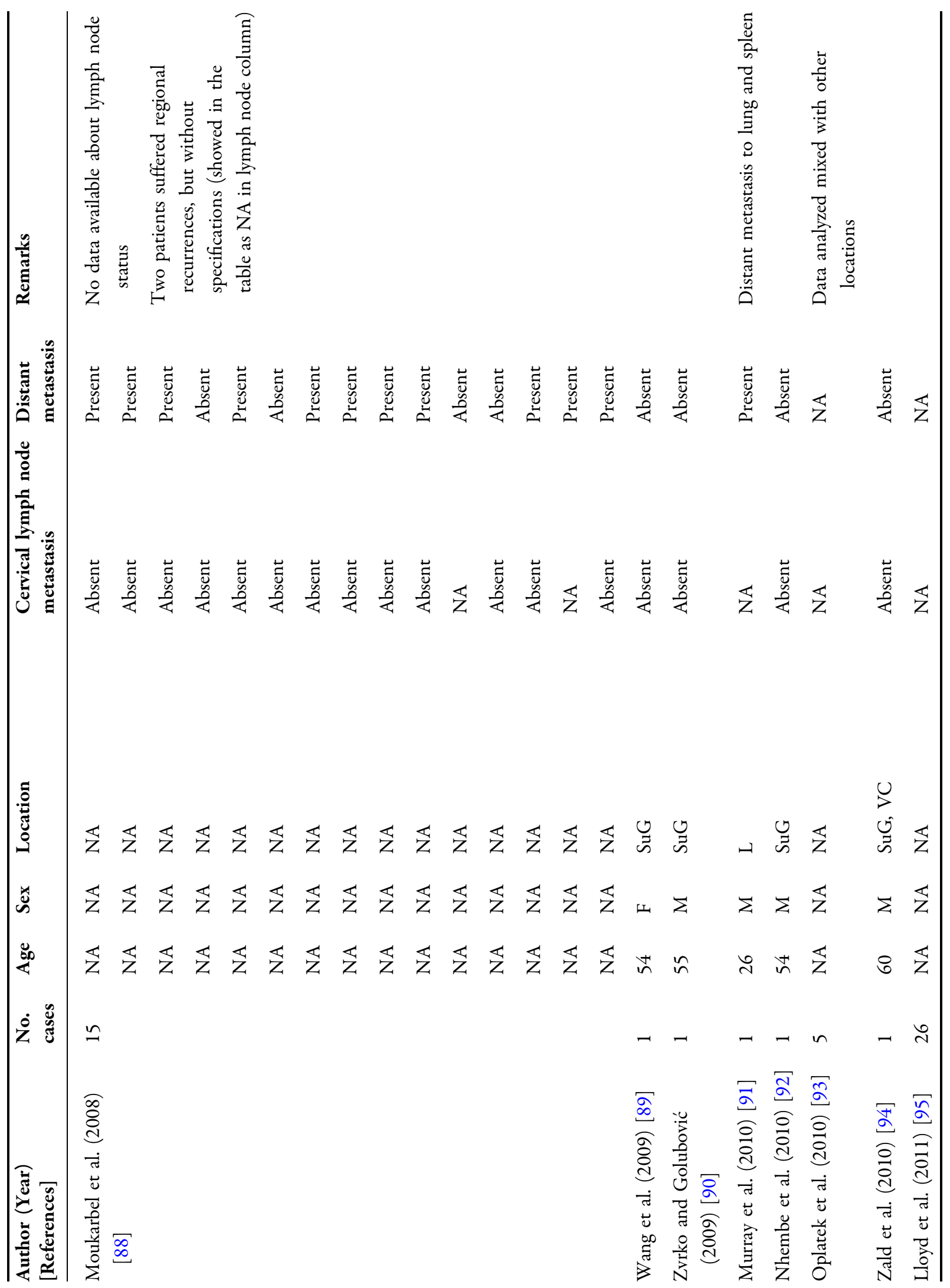




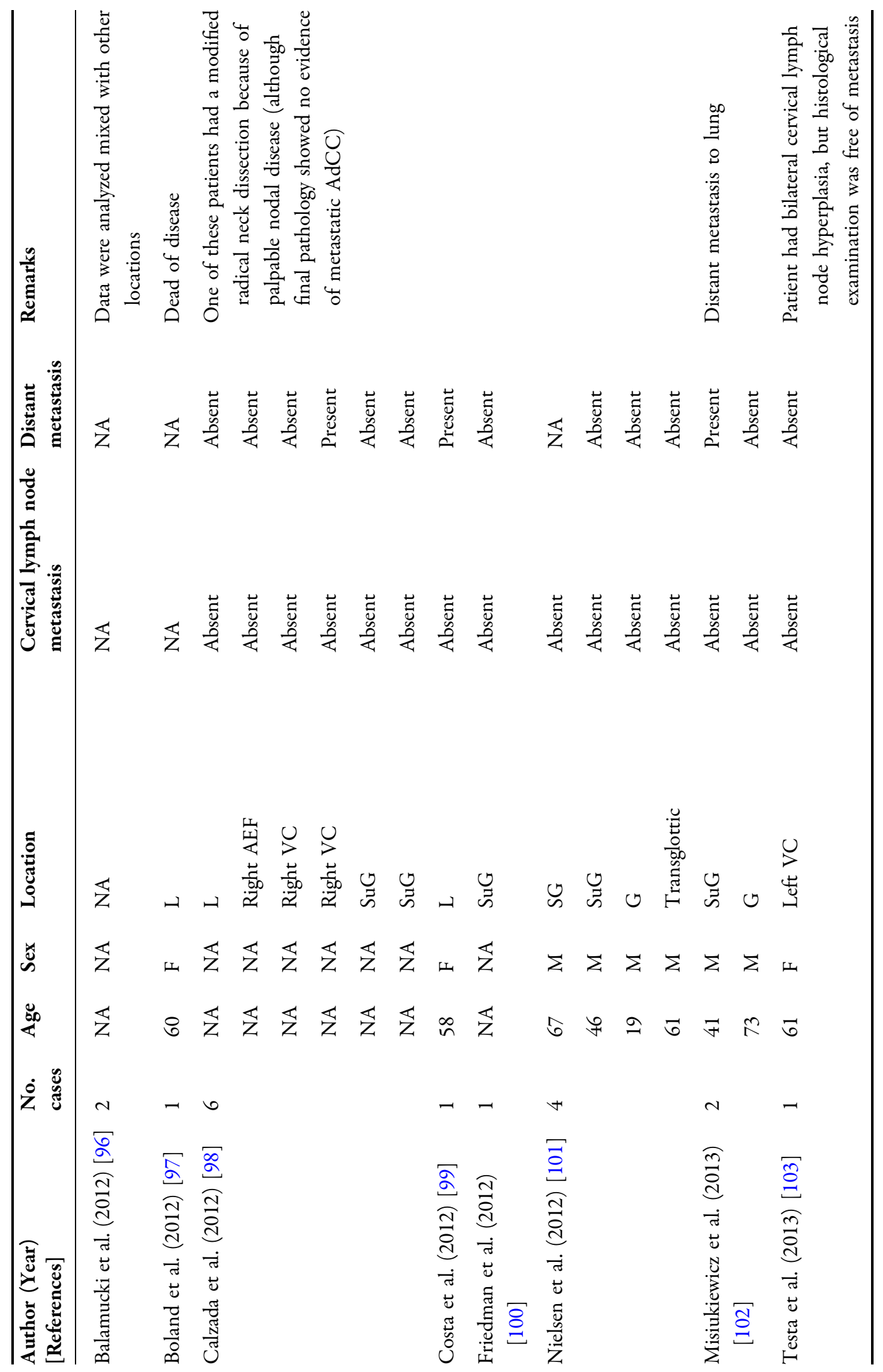




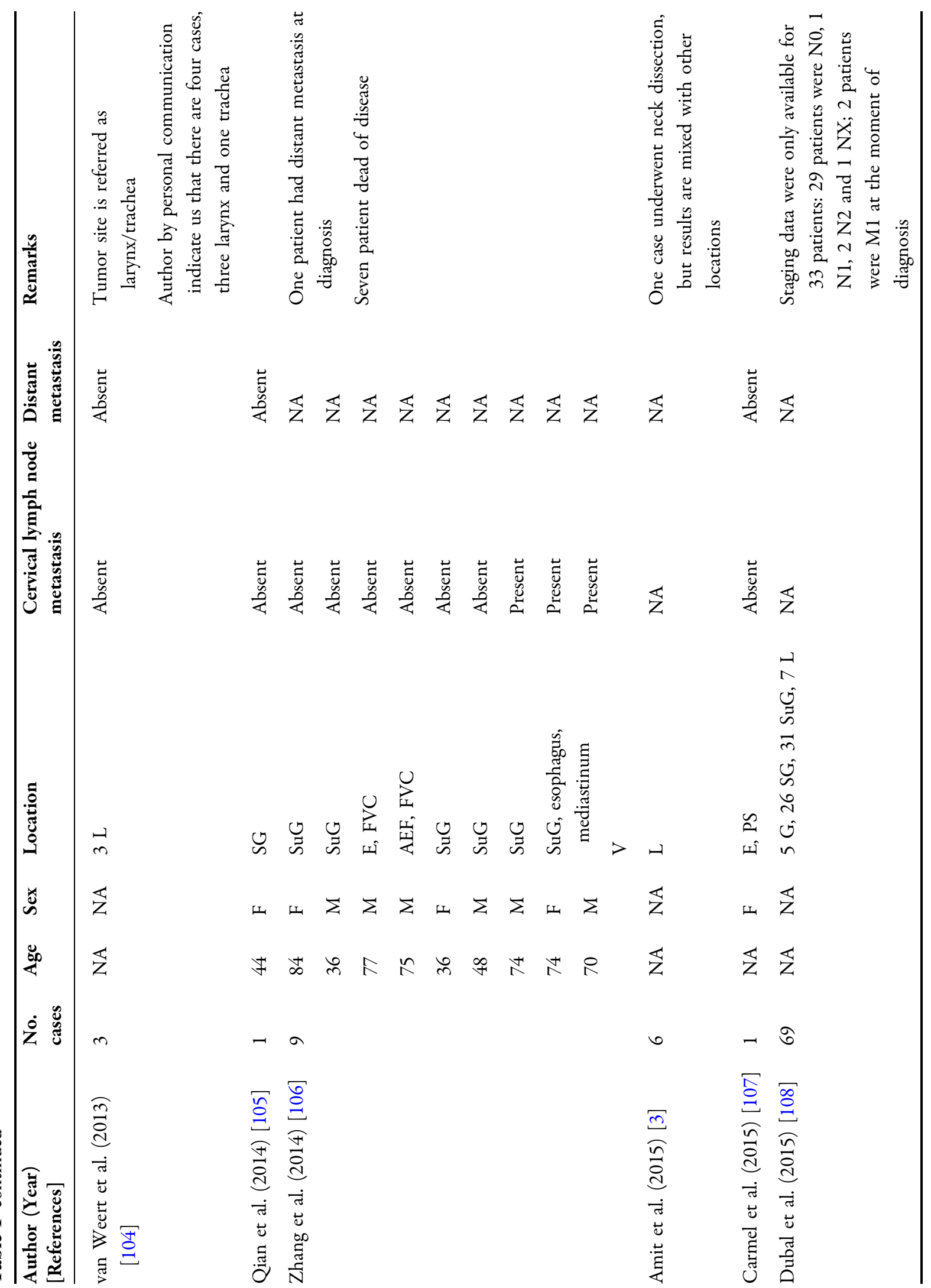




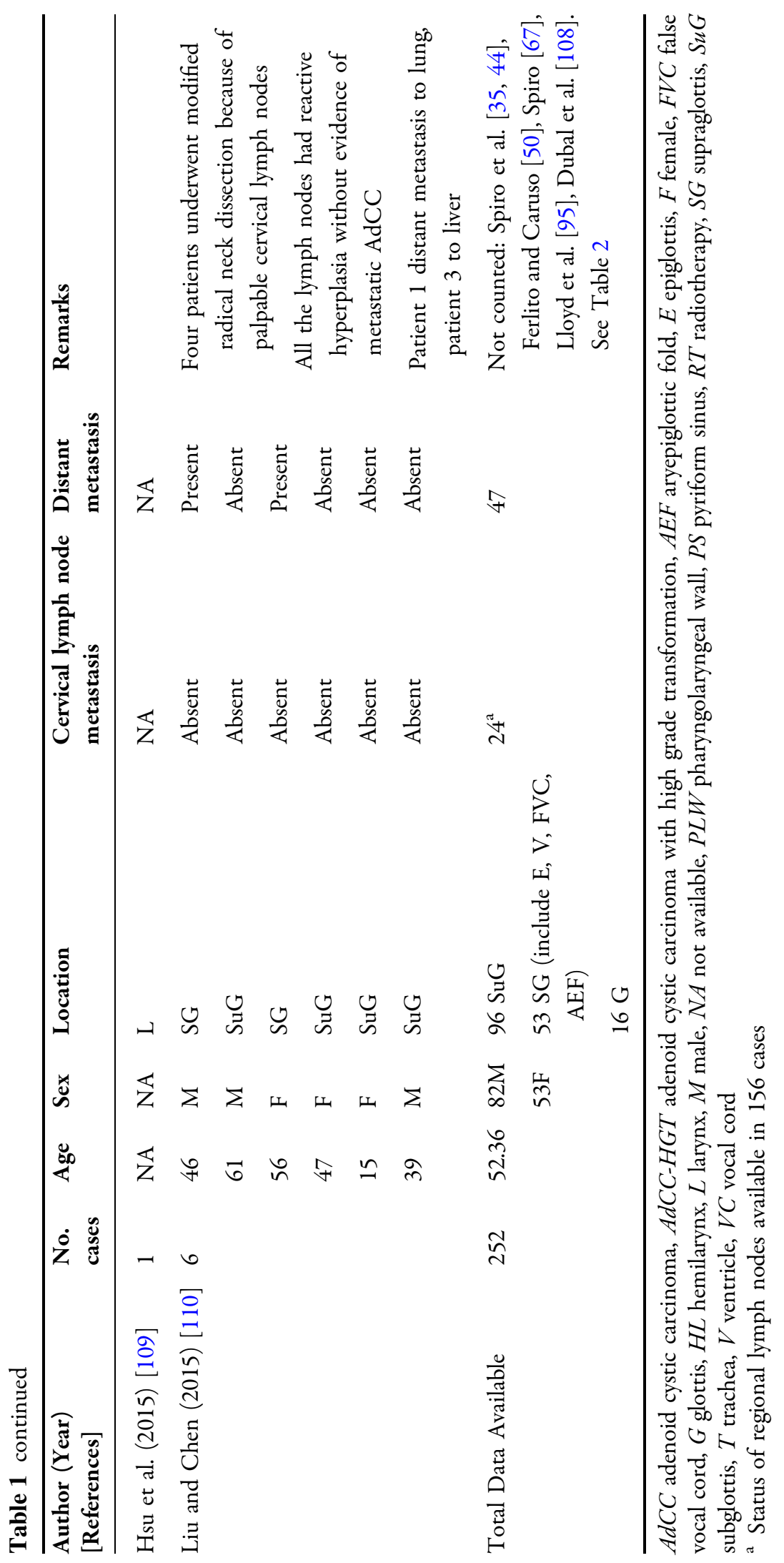




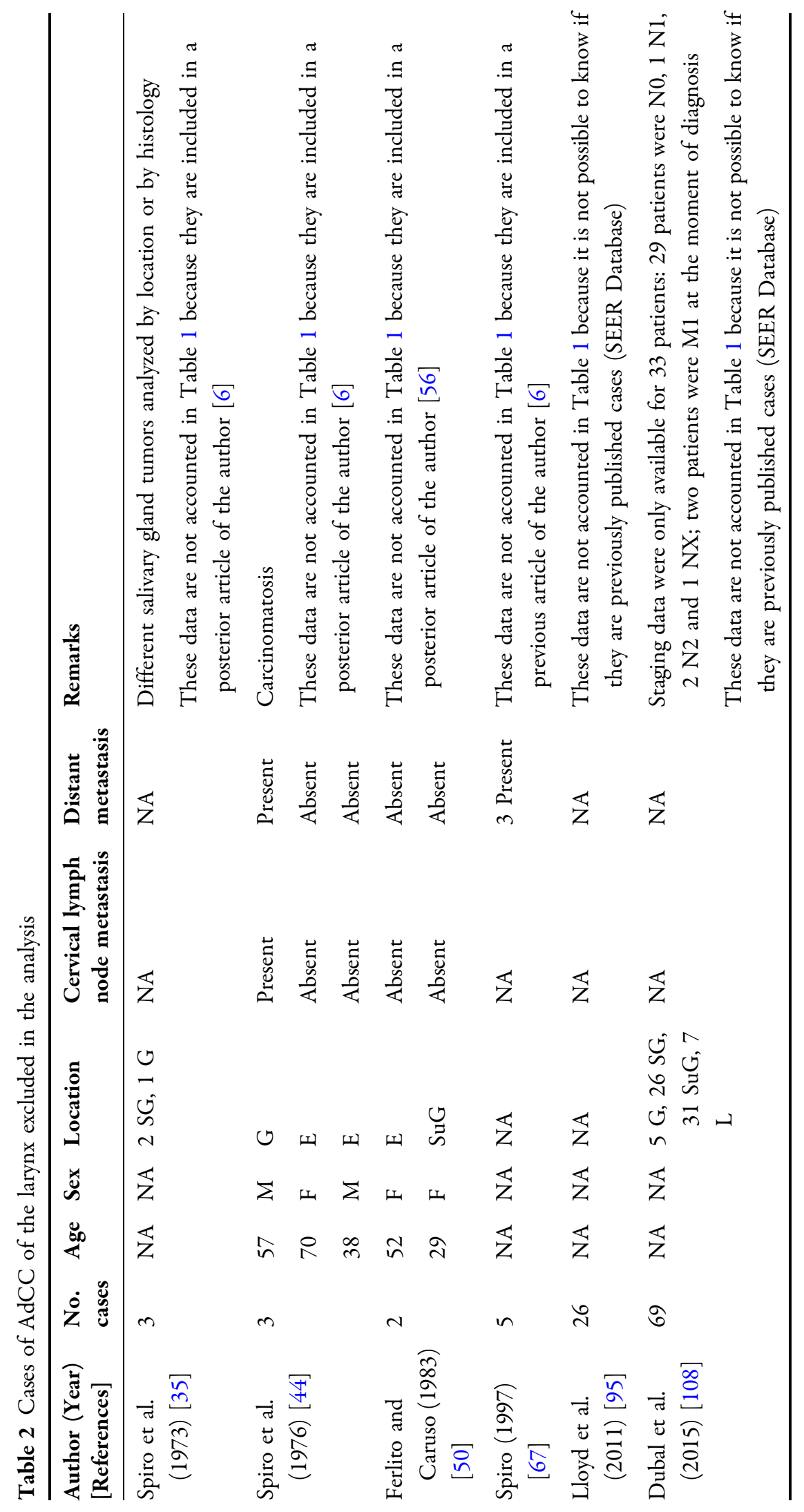


Table 3 Cases of reported adenoid cystic carcinoma of the larynx according to different time periods

\begin{tabular}{llllllll}
\hline Period & & No. of cases & Age & Sex & Location & $\begin{array}{l}\text { Cervical lymph } \\
\text { node metastasis }\end{array}$ & $\begin{array}{l}\text { Distant } \\
\text { metastasis }\end{array}$ \\
\hline A & $1912-1971$ & 43 & 48.28 & $20 \mathrm{M} / 10 \mathrm{~F}$ & $11 \mathrm{SG}, 2 \mathrm{G}, 13 \mathrm{SuG}$ & 3 Present $^{\mathrm{a}}$ & 7 Present \\
& $1972-1990$ & 67 & 55.44 & $23 \mathrm{M} / 18 \mathrm{~F}$ & $17 \mathrm{SG}, 6 \mathrm{G}, 26 \mathrm{SuG}$ & 10 Present $^{\mathrm{a}}$ & 12 Present \\
$\mathrm{B}$ & $1991-2015$ & 142 & 52.50 & $39 \mathrm{M} / 25 \mathrm{~F}$ & $25 \mathrm{SG}, 8 \mathrm{G}, 57 \mathrm{SuG}$ & 11 Present $^{\mathrm{b}}$ & 28 Present \\
$\mathrm{A}+\mathrm{B}$ & $1912-2015$ & 252 & 52.36 & $82 \mathrm{M} / 53 \mathrm{~F}$ & $53 \mathrm{SG}, 16 \mathrm{G}, 96 \mathrm{SuG}$ & 24 Present $^{\mathrm{c}}$ & 47 Present \\
\hline
\end{tabular}

$G$ glottis, $S G$ supraglottis, $S u G$ subglottis

${ }^{a}$ Status of regional lymph nodes available in 65 cases

b Status of regional lymph nodes available in 91 cases

c Status of regional lymph nodes available in 156 cases

\section{DISCUSSION}

Salivary gland carcinomas of the larynx are rare accounting for $<1 \%$ of laryngeal malignancies [116] and it has already been noted that among these AdCC is one of the most common. Their rarity may be in part related to the paucity of accessory salivary (mucoserous) glands in this region [110]. It is reminded that the highest number of minor glands is localized in the subglottis; but they are also seen in the supraglottis and only infrequently in the glottis [80]. Moukarbel et al. [88], in a 40-year experience at the Princess Margaret Hospital of Toronto identified only 15 cases of AdCC of the larynx and observed the most frequent location to be the subglotis (60\%). Others have also noted the predominant subglottic location of this tumor including Batsakis et al. [116] who found that 2 of their 3 tumors also arose in the subglottis as did 7 of the 10 tumors reported by Ganly et al. [80]. In our review of 252 cases of AdCC of the larynx, the exact location of the tumor was available in 165 and of these $58.2 \%$ arose in the subglottis, $32.1 \%$ in the supraglottis and $9.7 \%$ in the glottis.

AdCC has a distinct biological behavior as compared to other malignant tumors (slow growth, propensity to neurovascular invasion, high frequency of distant metastasis and long-term survival with tumor) [96]. Another characteristic of AdCC is that lymph node metastases are infrequent with a reported overall incidence of approximately 10\%, but this frequency may vary depending on the location of the lesion [e.g. base of tongue $(19.2 \%)$, mobile tongue (17.6\%), floor of mouth (15.3\%)] [117], and up to half of the patients with nasopharyngeal AdCC [118]. In our review of 252 cases of AdCC of the larynx, information regarding the status of the regional lymph nodes was available in only 156 cases and of these only 24 tumors (15.4\%) were associated with lymph node metastasis.

The finding of enlarged cervical lymph nodes in patients with AdCC of the larynx is however not uncommon. Liu and Chen [110] reviewed six cases of AdCC of the larynx four of which underwent modified radical neck dissection because of palpable cervical lymph nodes $(\mathrm{cN}+)$ and all four showed no evidence of metastasis on pathologic examination $(\mathrm{pN}-)$. Calzada et al. [98] identified, over a 30-year period, 11 patients with AdCC of the airway, six of which had tumors of the larynx. One of these patients underwent a modified radical neck 
dissection due to palpable nodal disease, but the pathologic analysis of the neck dissection specimen reported only reactive lymph nodes. Testa et al. [103], also reported one case of a glottic-subglottic AdCC with bilateral cervical lymph node hyperplasia but with no evidence of metastasis. In a national study conducted in Denmark, Nielsen et al. [101] found four cases of AdCC of the larynx. All were staged NO, including the patient in whom a suspicious node was surgically removed.

In contrast, in 1977, Olofsson and van Nostrand [45] reported four cases of AdCC of the larynx and 1 of them had metastatic foci in three small paraesophageal lymph nodes. More recently, Dubal et al. [108] reviewed 69 cases of laryngeal AdCC of which $87.9 \%$ of the patients were N0. The remaining patients were staged N1 (one patient), N2 (two patients) and $\mathrm{Nx}$ (one patient) using the American Joint Committee on Cancer staging system. Amit et al. [2] in their international collaborative study of 270 patients who underwent neck dissection for AdCC, identified two cases of AdCC of the larynx, and one of them had positive lymph nodes. In a similar paper of Amit et al. [3] they reviewed the same series of 270 patients who underwent neck dissection for AdCC. This time, the authors identified six patients with AdCC of the larynx and only one of which underwent elective neck dissection. The definite pathologic result of this neck dissection is unknown because the results of all neck dissections were analyzed together.

Considering these data, the incidence of lymph node metastasis seems to be very low, with anecdotal cases reported. There are however several reports that contradict this view. Spiro and Huvos [6] reported five patients with AdCC of the larynx, 4 (80\%) of which had associated lymph node metastasis.

\section{TREATMENT SUGGESTIONS}

Specific data on neck dissection in AdCC of the larynx are scarce. Therefore, we analyzed mainly the incidence of clinically overt lymph node metastasis in laryngeal AdCC. However, it can be anticipated that when this incidence is about $15.4 \%$ and the sensitivity of modern diagnostic techniques to detect occult lymph node metastasis is similar to that for head and neck squamous cell carcinoma, the rate of occult lymph node metastasis after current diagnostic work-up would be around $7 \%-8 \%$, probably too low to warrant elective neck dissection in this group. Moreover, patients will be more at risk for distant than cervical lymph node metastasis.

Adenoid cystic carcinoma with high grade transformation (AdCC-HGT), however, is another issue that requires special attention. High-grade transformation (previously referred to as dedifferentiation) is defined as the abrupt transformation of a tumor into high-grade morphology that lacks the original distinct histologic characteristics [119]. These changes may be focal within the tumor and, as a result, AdCC-HGT may not always be appreciated pre-operatively. AdCC-HGT is an aggressive tumor with a high tendency to recur and metastasize to the lymph nodes (at least 50\% or higher) and distant organs [120], as illustrated by the supraglottic tumor reported by Stillwagon et al. [52], which metastasized to five cervical lymph nodes with extracapsular extension, as well as to the liver, bone marrow, brain, heart, lungs and kidneys. AdCC-HGT must therefore be treated aggressively with due consideration for neck dissection.

The best treatment of the "conventional" laryngeal AdCC remains controversial. Standard treatment recommends a surgical approach 
with or without postoperative radiotherapy. Liu and Chen [110] reported six cases of laryngeal AdCC, all of which were treated with surgical resection and postoperative radiotherapy. They reported no local recurrences and only two patients had distant metastasis (lung and liver) with a maximum follow-up of 6 years. With respect to cervical nodes, they did not recommend neck dissection in the absence of palpable lymph nodes (elective neck dissection), considering that four cases with palpable lymph nodes $(\mathrm{cN}+)$ were all free of tumor on histologic evaluation ( $\mathrm{pN}-$ ). Postoperative radiotherapy was recommended in view of the submucosal and perineural pattern of spread of this tumor. This explains why partial procedures or even total laryngectomy in AdCC may result in positive margins. For example, Moukarbel et al. [88] only achieved tumor free margins in 5 of 15 patients. In three patients results were not available and seven had positive margins. Only three patients suffered local recurrence. In contrast, Calzada et al. [98] achieved tumor free surgical margins in 5 of 6 patients (the sixth patient's margin status was unavailable) including two patients who underwent partial surgery. All the patients received postoperative external beam radiotherapy. No cases of local recurrence were documented and only one patient had a distant failure.

In view of these data, neck dissection seems to be an overtreatment in patients with AdCC of the larynx. The reasons for not performing neck dissection are: very low incidence of cervical lymph node metastasis (probably under 15.4\%), low probability of neck recurrence (published cases with lymph node recurrences are anecdotal), need of complementary radiotherapy after the surgery due to the pattern of spread of this tumor (submucosal and perineural) and the low possibility of undiagnosed positive lymph nodes. The reasons against not performing neck dissection are: the option of performing a neck dissection with a very low morbidity during the "open" surgery for the primary tumor and the observation that the appearance of enlarged lymph nodes in patients with AdCC is not uncommon, raising doubts to the surgeon about the correct diagnosis or the correct treatment.

\section{LIMITATIONS}

After commenting on this information, we would like to point out several limitations of this review: first of all, we have tried to be extremely accurate reviewing the cases published and we have tried to include "all" the cases from the literature. We appreciate that in the first period assessed (1912-1990) several cases with inexact histologic diagnosis could be found, but in order to be comprehensive, they were included in this review. There are a lot of cases with relevant information missing, but we had to include the data given by the authors although some of them did not give information about $\mathrm{T}$ stage, histologic grading, node levels involved, etc. As we have stated above the majority of the articles are case reports, and there are a lot of review articles mixing the data of AdCC of different locations in the head and neck.

\section{CONCLUSION}

Based on a thorough literature review, lymph node metastases in AdCC of the larynx are infrequent. In general, elective treatment of the neck is recommended for patients with squamous cell carcinoma of the upper aerodigestive tract when the anticipated risk of 
occult metastasis is greater than $20 \%$, based on a widely quoted decision analysis model like that proposed by Weiss et al. [121]. According to this, for the most recent period 1991-2015, with a more precise diagnosis of the tumor, 142 cases were observed of AdCC of the larynx and between them 91 patients had data pertaining to lymph node status. Only eleven of the 91 patients (12.1\%) had nodal metastasis and in the previous period investigated (1912-1990) the incidence was also less than $20 \%$. Therefore we think that elective neck dissection is not indicated, particularly if the neck is carefully examined by ultrasound and ultrasound-guided fine-needle aspiration biopsy in diagnostic work-up and follow-up.

\section{ACKNOWLEDGMENTS}

No funding or sponsorship was received for this study or publication of this article. All named authors meet the International Committee of Medical Journal Editors (ICMJE) criteria for authorship for this manuscript, take responsibility for the integrity of the work as a whole, and have given final approval for the version to be published.

Disclosures. A. Coca-Pelaz, L. Barnes, A. Rinaldo, A. Cardesa, J. P. Shah, J. P. Rodrigo, C. Suárez, J. A. Eloy, J. A. Bishop, K. O. Devaney, L. D. R. Thompson, B. M. Wenig, P. Strojan, M. Hamoir, P. J. Bradley, D. R. Gnepp, C. E. Silver, P. J. Slootweg, A. Triantafyllou, V. Vander Poorten, M. D. Williams, A. Skálová, H. Hellquist, A. Teymoortash, J. E. Medina, K. T. Robbins, K. T. Pitman, L. P. Kowalski, R. de Bree, W. M. Mendenhall, R. P. Takes and A. Ferlito have nothing to disclose.
Compliance with Ethics Guidelines. This article is based on previously conducted studies and does not involve any new studies of human or animal subjects performed by any of the authors.

Open Access. This article is distributed under the terms of the Creative Commons Attribution-NonCommercial 4.0 International License (http://creativecommons.org/licenses/ by-nc/4.0/), which permits any noncommercial use, distribution, and reproduction in any medium, provided you give appropriate credit to the original author(s) and the source, provide a link to the Creative Commons license, and indicate if changes were made.

\section{REFERENCES}

1. Coca-Pelaz A, Rodrigo JP, Bradley PJ, et al. Adenoid cystic carcinoma-an update. Oral Oncol. 2015;51:652-61.

2. Amit M, Binenbaum Y, Sharma K, et al. Incidence of cervical lymph node metastasis and its association with outcomes in patients with adenoid cystic carcinoma. An international collaborative study. Head Neck. 2015;37:1032-7.

3. Amit M, Na'ara S, Sharma K, et al. Elective neck dissection in patients with head and neck adenoid cystic carcinoma: an international collaborative study. Ann Surg Oncol. 2015;22:1353-9.

4. Mills SE, Fechner RE. Larynx and pharynx. In: Sternberg SS, editor. Histology for pathologists. 2nd ed. Philadelphia: Lipincott-Raven; 1997. p. 391-403.

5. Eschwege F, Cachin Y, Micheau C. Treatment of adenocarcinomas of the larynx. Can J Otolaryngol. 1975;4:290-2.

6. Spiro RH, Huvos AG. Stage means more than grade in adenoid cystic carcinoma. Am J Surg. 1992;164:623-8. 
7. Tewfik TL, Novick WH, Schipper HM. Adenoid cystic carcinoma of the larynx. J Otolaryngol. 1983;12:151-4.

8. Broeckaert J. Ein Fall spontaner Heilung eines malignen Tumors (hyalogenes Cylindrom) des Larynx. Z Laryngol. 1912;5:51-6.

9. Bourgeois $\mathrm{H}$, Soulas A. A propos d'un cas de cylindrome de l'épiglottide avec métastases pulmonaires probables. Ann Otolaryngol. 1931;50:680-3.

10. Eigler G. Über Endotheliome, Peritheliome, Cylindrome und ähnliche Tumoren der oberen Luftwege. Arch Ohrenheilk. 1932;132:209-53.

11. Lemaître F, Ardoin G, Lemaître Y. Introduction a l'etude des tumeurs dites "cylindromes". Acta Otolaryngol. 1936;24:112-25.

12. Kramer R, Som ML. Cylindroma of the upper air passages. A cylindromatous type of mixed tumor. Arch Otolaryngol. 1939;29:356-70.

13. Ide D, Cahn HL. Subglottic cylindroma: with specific reference to its clinical course. Laryngoscope. 1948;58:328-35.

14. McDonald JR, Havens FZ. A study of malignant tumors of glandular nature found in the nose, throat and mouth. Surg Clin North Am. 1948;28:1087-106.

15. Pirodda E. Problemi di istopatologia del carcinoma del laringe. In: Il carcinoma del laringe. Atti XXXIX Congr Soc Ital Laringol Otol Rinol, Cagliari; 1951.

16. Berdal P, Mylius E. Cylindromas of the respiratory tract, the upper part of the digestive tract and adjoining organs. Acta Otolaryngol Suppl. $1954 ; 118: 32-44$.

17. Putney FJ, McStravog LJ. Salivary gland type tumors of the head and neck. Laryngoscope. 1954;64:285-97.

18. Abercromby BM, Rewell RE. Pleomorphic salivary adenoma (mixed parotid tumour) of the larynx. J Laryngol Otol. 1955;69:424-9.

19. Ahued S. Cylindroma of the epiglottis. AMA Arch Otolaryngol. 1956;63:366-71.

20. Murtagh JA, House RK. An atlas of otolaryngic pathology. New York: ARP; 1956.

21. Pietrantoni L, Leonardelli GB. Malignancy of cylindromas; anatomico-clinical data on 22 cases of cylindroma of the head. Ann Otolaryngol. 1957;74:15-31 (article in French).
22. Soboroff BJ. Cylindromas of the upper digestive and respiratory passages-a correlative study of their histologic patterns, clinical findings and modes of therapy. Laryngoscope. 1959;69:1381-410.

23. Leroux-Robert J, Poncet P, Dufourmentel P. Cylindrical epitheliomas of the pharynx and larynx. Ann Otolaryngol. 1961;78:534-45 (article in French).

24. Ash JE, Beck MR, Wilkes JD. Tumors of the upper respiratory tract and ear. Atlas of tumor pathology. Washington DC: Armed Forces Institute of Pathology; 1964.

25. Iosipescu A, Manolescu N. On some unusual localizations of cylindroma (laryngotracheobronchial localizations). Otorinolaringologie. 1965;10:63-8 (article in Romanian).

26. Rosenfeld L, Sessions DG, McSwain B, Graves H Jr. Malignant tumors of salivary gland origin: 37-year review of 184 cases. Ann Surg. 1966;163:726-35.

27. Toomey JM. Adenocarcinoma of the larynx. Laryngoscope. 1967;77:931-61.

28. Cady B, Rippey JH, Frazell EL. Non-epidermoid cancer of the larynx. Ann Surg. 1968;167:116-20.

29. Allachy R. Adenoid-cystic carcinoma of the larynx. J Laryngol Otol. 1969;83:1013-21.

30. Berdal P, de Besche A, Mylius E. Cylindroma of salivary glands. A report of 80 cases. Acta Otolaryngol Suppl. 1969;263:170-3.

31. Leonardelli GB, Pizzetti F. I tumori rari della laringe: patologia e clinica. Milano: Deca; 1970.

32. Adams GL, Duvall AJ 3rd. Adenocarcinoma of the head and neck. Arch Otolaryngol. 1971;93:261-70.

33. Pincini G, Mandelli PG. A proposito di un cilindroma sottoglottico. Minerva Otorinolaringol. 1971;21:219-23.

34. Jelínek R. Cylindroma of the epiglottis. Cesk Otolaryngol. 1973;22:58-9 (article in Czech).

35. Spiro RH, Koss LG, Hajdu SI, Strong EW. Tumors of minor salivary origin. A clinicopathologic study of 492 cases. Cancer. 1973;31:117-29.

36. Ackerman LV, Rosai J. Surgical pathology. 5th ed. St. Louis: CV Mosby Co; 1974.

37. Gross CW, Nakamura T, Maguda TA, Gros JC. Malignant minor salivary gland tumors. A report of 32 cases. Can J Otolaryngol. 1974;3:56-63. 
38. Muzaffar K, Bolstad DS. Adenoid cystic carcinoma of the larynx. Henry Ford Hosp Med Bull. 1974;22:91-6.

39. Whicker JH, Neel HB 3rd, Weiland LH, Devine KD. Adenocarcinoma of the larynx. Ann Otol. 1974;83:487-90.

40. Gerard M, De Gandt JB. A case of glotto-subglottic cylindroma. Acta Otorhinolaryngol Belg. 1975;29:692-5.

41. Sessions DG, Murray JP, Bauer WC, Ogura JH. Adenocarcinoma of the larynx. Can J Otolaryngol. $1975 ; 4: 293-6$.

42. Houle JA, Joseph P, Batsakis JG. Primary adenocarcinomas of the larynx. J Laryngol Otol. 1976;90:1159-63.

43. Kekelidze AA. Case of cylindroma of the larynx. Vestn Otorinolaringol. 1976;6:74-5 (article in Russian).

44. Spiro RH, Hajdu SI, Lewis JS, Strong EW. Mucus gland tumors of the larynx and laryngopharynx. Ann Otol. 1976;85:498-503.

45. Olofsson J, van Nostrand AW. Adenoid cystic carcinoma of the larynx: a report of four cases and a review of the literature. Cancer. 1977;40:1307-13.

46. Fleischer K, Glanz H, Kleinsasser O. Adenoid-cystic carcinoma of the larynx (author's transl). Laryngol Rhinol Otol (Stuttg). 1978;57:218-24 (article in German).

47. Mankodi RC, Shah RM. Laryngeal adenoidcystic carcinoma. J Postgrad Med. 1979;25:115-6.

48. Marsh WL Jr, Allen MS Jr. Adenoid cystic carcinoma: biologic behavior in 38 patients. Cancer. 1979;43:1463-73.

49. Donovan DT, Conley J. Adenoid cystic carcinoma of the subglottic region. Ann Otol. 1983;92:491-5.

50. Ferlito A, Caruso G. Biological behaviour of laryngeal adenoid cystic carcinoma. Therapeutic considerations. ORL J Otorhinolaryngol Relat Spec. 1983;45:245-56.

51. Cohen J, Guillamondegui OM, Batsakis JG, Medina JE. Cancer of the minor salivary glands of the larynx. Am J Surg. 1985;150:513-8.

52. Stillwagon GB, Smith RR, Highstein C, Lee DJ. Adenoid cystic carcinoma of the supraglottic larynx: report of a case and review of the literature. Am J Otolaryngol. 1985;6:309-14.
53. Gadomski SP, Zwillenberg D, Choi HY. Non-epidermoid carcinoma of the larynx: the Thomas Jefferson University experience. Otolaryngol Head Neck Surg. 1986;95:558-65.

54. Jones AS, Lancer JM, Smith CM. A rare, resectable cause of progressive obstructive airways diseases. J R Coll Surg Edinb. 1986;31:319-21.

55. Li TS. Adenoid cystic carcinoma of the larynx. Zhonghua Zhong Liu Za Zhi. 1988;10:465-6 (article in Chinese).

56. Ferlito A, Barnes L, Myers EN. Neck dissection for laryngeal adenoid cystic carcinoma: is it indicated? Ann Otol Rhinol Laryngol. 1990;99:277-80.

57. Paredes Osado JR, Cerdán Baeza FJ, Talavera Sánchez J. Adenoid cystic subglottic carcinoma. A case report. Acta Otorrinolaringol Esp. 1990;41:245-8 (article in Spanish).

58. Dueñas Parrilla JM, Alvarez Bautista A, Sánchez Gómez S, Tirado Zamora I. Cystic adenoid carcinoma of the larynx. Presentation of a case and review of the literature. Acta Otorrinolaringol Esp. 1991;42:67-70 (article in Spanish).

59. Serafini I, Lucioni M, Bittesini L, Dei Tos AP, Della Libera D. Treatment of laryngeal adenoid cystic carcinoma. Acta Otorhinolaryngol Ital. 1991;11:13-24 (article in Italian).

60. Bignardi L, Aimoni C, Franceschetti E, Galcerán M, Rabitti C. Adenoid cystic carcinoma of the larynx: review of the literature and caseload. Acta Otorrinolaringol Esp. 1993;44:141-5 (article in Spanish).

61. Gierek T, Kołodziejczyk M, Kajor M. Primary adenoid carcinoma of the larynx and upper part of trachea. Otolaryngol Pol. 1994;48:536-9 (Article in Polish).

62. Anderson JN Jr, Beenken SW, Crowe R, et al. Prognostic factors in minor salivary gland cancer. Head Neck. 1995;17:480-6.

63. de Kerviler E, Bely N, Laccourreye O, Clément O, Halimi P, Frija G. The aryepiglottic fold as a rare location of adenoid cystic carcinoma. AJNR Am J Neuroradiol. 1995;16:1375-7.

64. Scott PM, Glover GW. All that wheezes is not asthma. Br J Clin Pract. 1995;49:43-4.

65. Lam KY, Yuen AP. Cancer of the larynx in Hong Kong: a clinico-pathological study. Eur J Surg Oncol. 1996;22:166-70. 
66. Parsons JT, Mendenhall WM, Stringer SP, Cassisi NJ, Million RR. Management of minor salivary gland carcinomas. Int J Radiat Oncol Biol Phys. 1996;35:443-54.

67. Spiro RH. Distant metastasis in adenoid cystic carcinoma of salivary origin. Am J Surg. 1997;174:495-8.

68. Srivastava R, Bhatia N. Adenoid cystic carcinoma of larynx. Indian J Otolaryngol Head Neck Surg. 1997;49:280-1.

69. Alavi S, Namazie A, Calcaterra TC, Blackwell KE. Glandular carcinoma of the larynx: the UCLA experience. Ann Otol Rhinol Laryngol. 1999;108:485-9.

70. Damborenea Tajada J, Campos del Alamo MA, Marín García J, Leache Pueyo J, Llorente Arenas E, Fernández Liesa R. Adenoid cystic carcinoma of the larynx. Case report and literature review. An Otorrinolaringol Ibero Am. 1999;26:257-63 (article in Spanish).

71. Fordice J, Kershaw C, El-Naggar A, Goepfert H. Adenoid cystic carcinoma of the head and neck: predictors of morbidity and mortality. Arch Otolaryngol Head Neck Surg. 1999;125:149-52.

72. Hogg RP, Kuo MJ, Olliff J, Das Gupta AR. Invasion of the recurrent laryngeal nerve by adenoid cystic carcinoma. An unusual cause of true vocal fold paralysis. J Laryngol Otol. 1999;113:260-2.

73. Morais Pérez D, Cortejoso Hernández A, Borau Clavero M, Martín Sigüenza G. Adenoid cystic carcinoma of the larynx. Acta Otorrinolaringol Esp. 1999;50:660-3 (article in Spanish).

74. Veivers D, de Vito A, Luna-Ortiz K, Brasnu D, Laccourreye O. Supracricoid partial laryngectomy for non-squamous cell carcinoma of the larynx. J Laryngol Otol. 2001;115:388-92.

75. Javadi M, Bafrouee FM, Mohseni M, Asghari A. Laryngeal adenoid cystic carcinoma in a child: a case report. Ear Nose Throat J. 2002;81:34-5.

76. Mahlstedt K, Ussmüller J, Donath K. Malignant sialogenic tumours of the larynx. J Laryngol Otol. 2002;116:119-22.

77. Lee LA, Fang TJ, Li HY, Lee KF. Adenoid cystic carcinoma of the supraglottis mimicking a laryngeal cyst. Otolaryngol Head Neck Surg. 2003;129:157-8.

78. Silverman DA, Carlson TP, Khuntia D, Bergstrom RT, Saxton J, Esclamado RM. Role for postoperative radiation therapy in adenoid cystic carcinoma of the head and neck. Laryngoscope. 2004;114:1194-9.

79. Gaissert HA, Grillo HC, Shadmehr BM, et al. Laryngotracheoplastic resection for primary tumors of the proximal airway. J Thorac Cardiovasc Surg. 2005;129:1006-9.

80. Ganly I, Patel SG, Coleman M, Ghossein R, Carlson D, Shah JP. Malignant minor salivary gland tumors of the larynx. Arch Otolaryngol Head Neck Surg. 2006;132:767-70.

81. Fletcher CDM. Diagnostic histopathology of tumors. 2nd ed. New York: Churchill Livingstone; 2000.

82. Haddad RI, Posner MR, Busse PM, et al. Chemoradiotherapy for adenoid cystic carcinoma: preliminary results of an organ sparing approach. Am J Clin Oncol. 2006;29:153-7.

83. Khan AR, Jan A, Nawaz G, Zaman N. Adenoid cystic carcinoma of larynx. J Coll Physicians Surg Pak. 2006;16:669-70.

84. Wang MC, Liu CY, Li WY, Chang SY, Chu PY. Salivary gland carcinoma of the larynx. J Chin Med Assoc. 2006;69:322-5.

85. Del Negro A, Ichihara E, Tincani AJ, Altemani A, Martins AS. Laryngeal adenoid cystic carcinoma: case report. Sao Paulo Med J. 2007;125:295-6.

86. Messaoudi C, Larouk R, Baili S, et al. Adenoid cystic carcinoma of the larynx. A case report and review of the literature. Rev Laryngol Otol Rhinol (Bord). 2007;128:97-100 (article in French).

87. Aydin O, Ustünda $\breve{g} \mathrm{E}$, Işeri M, Erçin C. Laryngeal adenoid cystic carcinoma in an adolescent. Kulak Burun Bogaz Ihtis Derg. 2008;18:319-22.

88. Moukarbel RV, Goldstein DP, O'Sullivan B, et al. Adenoid cystic carcinoma of the larynx: a 40-year experience. Head Neck. 2008;30:919-24.

89. Wang HL, Xu L, Li FJ. Subglottic adenoid cystic carcinoma mistaken for asthma. J Zhejiang Univ Sci B. 2009;10:707-10.

90. Zvrko E, Golubović M. Laryngeal adenoid cystic carcinoma. Acta Otorhinolaryngol Ital. 2009;29:279-82.

91. Murray BW, Lyons LC, Mancino AT, Huerta S. A report of laryngeal adenocystic carcinoma metastatic to the spleen and the role of splenectomy in the management of metastatic disease: a case report. J Med Case Rep. 2010;4:207. 
92. Nhembe F, Jerjes W, Upile T, Hamdoon Z, Vaz F, Hopper C. Subglottic carcinoma treated with surgery and adjuvant photodynamic therapy. Photodiagnosis Photodyn Ther. 2010;7:284-7.

93. Oplatek A, Ozer E, Agrawal A, Bapna S, Schuller DE. Patterns of recurrence and survival of head and neck adenoid cystic carcinoma after definitive resection. Laryngoscope. 2010;120:65-70.

94. Zald PB, Weber SM, Schindler J. Adenoid cystic carcinoma of the subglottic larynx: a case report and review of the literature. Ear Nose Throat J. 2010;89:E27-32.

95. Lloyd S, Yu JB, Wilson LD, Decker RH. Determinants and patterns of survival in adenoid cystic carcinoma of the head and neck, including an analysis of adjuvant radiation therapy. Am J Clin Oncol. 2011;34:76-81.

96. Balamucki CJ, Amdur RJ, Werning JW, et al. Adenoid cystic carcinoma of the head and neck. Am J Otolaryngol. 2012;33:510-8.

97. Boland JM, McPhail ED, García JJ, Lewis JE, Schembri-Wismayer DJ. Detection of human papilloma virus and p16 expression in high-grade adenoid cystic carcinoma of the head and neck. Mod Pathol. 2012;25:529-36.

98. Calzada AP, Miller M, Lai CK, Elashoff DA, Abemayor E, St John MA. Adenoid cystic carcinoma of the airway: a 30-year review at one institution. Am J Otolaryngol. 2012;33:226-331.

99. Costa AF, Tasso MG, Mariano FV, Soares AB, Chone CT, Crespo AN, Fresno MF, Llorente JL, Suárez C, de Araújo VC, Hermsen M, Altemani A. Levels and patterns of expression of hypoxia-inducible factor- $1 \alpha$, vascular endothelial growth factor, glucose transporter-1 and CD105 in adenoid cystic carcinomas with high-grade transformation. Histopathology. 2012;60:816-25.

100. Friedman AD, Burns JA, Lutch MJ, Zeitels SM. Submucosal neoplasms of the laryngeal introitus. J Laryngol Otol. 2012;126:706-13.

101. Nielsen TK, Bjørndal K, Krogdahl A, et al. Salivary gland carcinomas of the larynx: a national study in Denmark. Auris Nasus Larynx. 2012;39:611-4.

102. Misiukiewicz KJ, Camille N, Tishler R, Haddad R, Limaye S, Posner $M$. Organ preservation for adenoid cystic carcinoma of the larynx. Oncologist. 2013;18:579-83.

103. Testa D, Guerra G, Conzo G, et al. Glottic-subglottic adenoid cystic carcinoma. A case report and review of the literature. BMC Surg. 2013;13:S48.
104. van Weert S, Bloemena E, van der Waal I, et al. Adenoid cystic carcinoma of the head and neck: a single-center analysis of 105 consecutive cases over a 30-year period. Oral Oncol. 2013;49:824-9.

105. Qian X, Zhou H, Gu Y, Zhang Y, Gao X. Supraglottic adenoid cystic carcinoma mimicking laryngeal amyloidosis: a case report. Oncol Lett. 2014;7:2154-6.

106. Zhang M, Li KN, Li C, Zhou L, Zhu JX, Wang SY. Malignant minor salivary gland carcinomas of the larynx. ORL J Otorhinolaryngol Relat Spec. 2014;76:222-6.

107. Carmel NN, Brazowski E, Oestreicher-Kedem Y. Laryngeal mass. JAMA Otolaryngol Head Neck Surg. 2015;141:179-80.

108. Dubal PM, Svider PF, Folbe AJ, et al. Laryngeal adenoid cystic carcinoma: a population-based perspective. Laryngoscope. 2015;125:2485-90.

109. Hsu AA, Tan EH, Takano AM. Lower respiratory tract adenoid cystic carcinoma: its management in the past decades. Clin Oncol (R Coll Radiol). 2015;27:732-40.

110. Liu W, Chen X. Adenoid cystic carcinoma of the larynx: a report of six cases with review of the literature. Acta Otolaryngol. 2015;135:489-93.

111. Wain SL, Kier R, Vollmer RT, Bossen EH. Basaloid-squamous carcinoma of the tongue, hypopharynx, and larynx: report of 10 cases. Hum Pathol. 1986;17:1158-66.

112. Freedman PD, Lumerman H. Lobular carcinoma of intraoral minor salivary gland origin. Report of twelve cases. Oral Surg Oral Med Oral Pathol. 1983;56:157-66.

113. Donath K, Seifert G, Schmitz R. Diagnosis and ultrastructure of the tubular carcinoma of salivary gland ducts. Epithelial-myoepithelial carcinoma of the intercalated ducts. Virchows Arch A Pathol Pathol Anat. 1972;356:16-31 (article in German).

114. Michal M, Skálová A, Simpson RH, et al. Cribriform adenocarcinoma of the tongue: a hitherto unrecognized type of adenocarcinoma characteristically occurring in the tongue. Histopathology. 1999;35:495-501.

115. Ellis GL, Gnepp DR. Unusual salivary gland tumors: basal cell adenocarcinoma. In: Gnepp DR, editor. Pathology of the head and neck. New York: Churchill Livingstone; 1988. p. 617-23.

116. Batsakis JG, Luna MA, El-Naggar AK. Nonsquamous carcinomas of the larynx. Ann Otol Rhinol Laryngol. 1992;101:1024-6. 
117. Min R, Siyi L, Wenjun Y, et al. Salivary gland adenoid cystic carcinoma with cervical lymph node metastasis: a preliminary study of 62 cases. Int J Oral Maxillofac Surg. 2012;41:952-7.

118. Schramm VL Jr, Imola MJ. Management of nasopharyngeal salivary gland malignancy. Laryngoscope. 2001;111:1533-44.

119. Nagao T. "Dedifferentiation" and high-grade transformation in salivary gland carcinomas. Head Neck Pathol. 2013;7:S37-47.
120. Seethala RR, Hunt JL, Baloch ZW, Livolsi VA, Barnes EL. Adenoid cystic carcinoma with high-grade transformation: a report of 11 cases and a review of the literature. Am J Surg Pathol. 2007;31:1683-94.

121. Weiss MH, Harrison LB, Isaacs RS. Use of decision analysis in planning a management strategy for the stage NO neck. Arch Otolaryngol Head Neck Surg. 1994;120:699-702. 